107 Royal Netherlands Institute for Sea Research

This is a postprint of:

Svensson, E., Freitas, V., Schouten, S., Middelburg, J.J., van der Veer, H.W. \& Sinninghe Damsté, J.S. (2014). Comparison of the stable carbon and nitrogen isotopic values of gill and white muscle tissue of fish. Journal of Experimental Marine Biology and Ecology, 457, 173-179

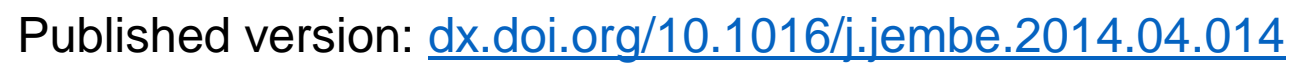

Link NIOZ Repository: $\underline{w w w . v l i z . b e / n l / i m i s ? m o d u l e=r e f \& r e f i d=240825 ~}$

[Article begins on next page]

The NIOZ Repository gives free access to the digital collection of the work of the Royal Netherlands Institute for Sea Research. This archive is managed according to the principles of the Open Access Movement, and the Open Archive Initiative. Each publication should be cited to its original source - please use the reference as presented.

When using parts of, or whole publications in your own work, permission from the author(s) or copyright holder(s) is always needed. 
Please cite as: Svensson E., Freitas V., Schouten S., Middelburg J. J., van der Veer H. W. and Sinninghe Damsté J. S. (2014) Comparison of the stable carbon and nitrogen isotopic values of gill and white muscle tissue of fish. Journal of Experimental Marine Biology and Ecology 457, 173-179. DOI: 10.1016/j.jembe.2014.04.014

\title{
Comparison of the stable carbon and nitrogen isotopic values of gill and white muscle tissue of fish
}

\author{
Elisabeth Svensson ${ }^{a}$, Vânia Freitas ${ }^{a, b}$, Stefan Schouten ${ }^{a, c}$, Jack J. Middelburg ${ }^{c}$, Henk W. van der Veer ${ }^{a}$, \\ Jaap S. Sinninghe Damstéa,c \\ ${ }^{a}$ Departments of Marine Organic Biogeochemistry and Marine Ecology, NIOZ Royal Netherlands \\ Institute for Sea Research, P.O. Box 59, 1790 AB Den Burg (Texel), The Netherlands \\ ${ }^{\mathrm{b}}$ Interdisciplinary Centre of Marine and Environmental Research (CIIMAR/CIMAR), University of Porto, \\ Rua dos Bragas 289, P 4050-123 Porto, Portugal \\ ${ }^{\mathrm{c}}$ Faculty of Geosciences, Utrecht University, PO Box 80021, 3508 TA Utrecht, The Netherlands \\ *Corresponding author: \\ Elisabeth Svensson \\ E-mail: elisabeth.svensson@nioz.nl, esvensson@gmail.com \\ Phone: $+31(222) 369584$ \\ ORCID: 0000-0002-5565-3266
}

\begin{abstract}
The potential use of stable carbon and nitrogen isotope ratios $\left(\delta^{13} \mathrm{C}, \delta^{15} \mathrm{~N}\right)$ of fish gills for studies on fish feeding ecology was evaluated by comparing the $\delta^{13} \mathrm{C}$ and $\delta^{15} \mathrm{~N}$ of gill tissue with the more commonly used white muscle tissue. To account for the effect of lipid content on the $\delta^{13} \mathrm{C}$ signatures, a study-specific lipid correction model based on $\mathrm{C}: \mathrm{N}$ ratios was developed and applied to the bulk $\delta^{13} \mathrm{C}$ data. For the majority of species in the study, we found no significant difference in $\delta^{13} \mathrm{C}$ values between gill and muscle tissue after correction, but several species showed a small $(0.3-1.4 \%$ ) depletion in ${ }^{13} \mathrm{C}$ in white muscle compared to gill tissue. The average species difference in $\delta{ }^{15} \mathrm{~N}$ between muscle and gill tissue ranged from -0.2 to $1.6 \%$ for the different fish species with muscle tissue generally more enriched in ${ }^{15} \mathrm{~N}$. The $\delta^{13} \mathrm{C}$ values of muscle and gill were strongly linearly correlated $\left(R^{2}=0.85\right)$ over a large isotopic range $(13 \%)$, suggesting that both tissues can be used to determine long-term feeding or migratory habits of fish. Muscle and gill tissue bulk $\delta^{15} \mathrm{~N}$ values were also strongly positively correlated $\left(R^{2}=0.76\right)$ but with a small difference between muscle and gill tissue. This difference indicates that the bulk $\delta^{15} \mathrm{~N}$ of the two tissue types may be influenced by different isotopic turnover rates or a different composition of amino acids.
\end{abstract}

Keywords: $\delta^{13} \mathrm{C} ; \quad \delta^{15} \mathrm{~N}$; fish gills; fish muscle; lipid correction; stable isotopes

\section{Introduction}

In the last decades, stable isotope ratios of carbon $\left(\delta^{13} \mathrm{C}\right)$ and nitrogen $\left(\delta^{15} \mathrm{~N}\right)$ have become widely used tools in ecology (e.g. Boecklen et al., 2011; Fry, 2006). As the ease of analysis and availability of analytical facilities has greatly increased, there has been a veritable explosion in the number of studies applying stable isotopes to examine e.g. animal migration, trophic interactions and carbon flow through ecosystems (Boecklen et al., 2011; and references therein). Generally, the $\delta^{13} \mathrm{C}$ signal changes little during trophic transfer (DeNiro and Epstein, 1978; Haines, 1976; Minson et al., 1975), and carbon isotopes are therefore mainly used to distinguish between food sources based on the difference in $\delta^{13} \mathrm{C}$ signals between e.g. marine primary producers and terrestrial $\mathrm{C} 3$ and C4 plants (e.g. Boecklen et al., 2011; Fry et al., 1977; Hobson, 1999). As the $\delta^{15} \mathrm{~N}$ signal changes by on average 3\%o per trophic level (Minagawa and Wada, 1984; Schoeninger and DeNiro, 
1984), it is widely used for studies on trophic interactions (e.g. DeNiro and Epstein, 1981; Minagawa and Wada, 1984).

Stable isotope analysis is useful to examine habitat utilization and trophic ecology of fish in estuarine and coastal waters (Buchheister and Latour, 2010; Vinagre et al., 2011, 2008). However, due to the mobile nature of fish, spatial and temporal variability in stable isotopic signatures need to be taken into account for a correct interpretation of diet studies. The combined analysis of the stable isotope ratios from multiple tissues with different turnover times can potentially provide important information on seasonal variability in feeding habits (Dalerum and Angerbjörn, 2005). Most studies on stable isotopes in fish have focused on white and red muscle tissues (see e.g. Boecklen et al., 2011; and references therein), which integrate the isotopic signature of the food source on a relatively long time span (months to a year) (Buchheister and Latour, 2010; Hesslein et al., 1993; MacAvoy et al., 2001). In contrast, the isotopic signature of liver, a regulatory tissue with fast turnover times (weeks to months), has been shown to be responsive to changes in food sources throughout the year (Perga and Gerdeaux, 2005). Studies on other tissues such as gills, fins, and scales are much less prevalent (Graham et al., 2013; Jardine et al., 2005; Serrano et al., 2007; Vollaire et al., 2007). Due to the high blood flow through fish gills, it is assumed that the turnover time in this tissue is relatively short, which could potentially make them suitable for studies of short-term diet changes. The few studies that report the stable carbon isotopic signatures of fish gills show a significant difference between the $\delta^{13} \mathrm{C}$ of muscle and gill tissue (Vollaire et al., 2007). One cause for differences in ${ }^{13} \mathrm{C}$ content between different types of tissues in animals is lipid content. Due to fractionation processes during lipid biosynthesis (DeNiro and Epstein, 1977; Monson and Hayes, 1982), lipids are depleted in $\delta^{13} \mathrm{C}$ by approx. 6-8\% compared to proteins and carbohydrates, and a high lipid content could have a significant impact on the $\delta^{13} \mathrm{C}$ signature of gills. The lipid content of a tissue is influenced by several factors besides just the food source (e.g. species, tissue type, reproductive stage, gender, nutritional state), and a high or highly variable lipid content can therefore mask the dietary $\delta^{13} \mathrm{C}$ signal, thereby making inter- or intra species comparisons and diet reconstructions difficult (Ehrich et al., 2011; Hoffman and Sutton, 2010; Post et al., 2007). Indeed, it has been reported that the lipid content in gills may vary substantially between species and with growth conditions (Serrano et al., 2007; Vollaire et al., 2007). To remove the effects of varying lipid content on the $\delta^{13} \mathrm{C}$ signal, lipids can be chemically extracted from the tissue prior to analysis. This procedure, however, is quite time consuming, which makes it difficult to process large numbers of samples as required for ecological applications. In addition, use of different extraction methods, which are more or less selective and efficient towards different types of lipids, complicates interstudy comparisons (e.g. Iverson et al., 2001; Logan and Lutcavage, 2008).

As an alternative to the laborious lipid extraction, lipid correction models are frequently used to predict the effect of lipid $\delta^{13} \mathrm{C}$ on the bulk $\delta^{13} \mathrm{C}$ signal (Abrantes et al., 2012; Logan et al., 2008; McConnaughey and McRoy, 1979; Post et al., 2007). McConnaughey and McRoy (1979) proposed one of the earlier models to calculate the $\delta^{13} \mathrm{C}$ values of lipid-free tissue. These authors used a constant fractionation of $6 \%$ o between proteins and lipids and the C: $\mathrm{N}$ ratio of the samples, a parameter that is routinely obtained during isotope analysis, was used as a proxy for lipid content. Later studies, building on the relationship between the $\mathrm{C}: \mathrm{N}$ ratio and lipid content (\%lipid), established correlations between the $\mathrm{C}: \mathrm{N}$ ratio and the difference in $\delta^{13} \mathrm{C}$ values of lipid-free and bulk tissue $\left(\Delta \delta^{13} \mathrm{C}\right)$, and used this to estimate the $\delta^{13} \mathrm{C}$ values of lipid-free tissue (e.g. Abrantes et al., 2012; Bodin et al., 2007; Hoffman and Sutton, 2010; Logan et al., 2008; Post et al., 2007). One of the more widely applied correction models was proposed by Post et al. (2007), who determined a linear relationship between the $\mathrm{C}: \mathrm{N}$ ratio and $\Delta \delta^{13} \mathrm{C}$ based on muscle tissue or whole organisms for a large sample set of aquatic and terrestrial plants and animals. However, several studies have 
shown that generalized models may over- or under estimate the effect of lipid content on the $\delta^{13} C_{\text {bulk }}$ signal when applied to different species and tissue types, and it is therefore suggested that study-specific models should be implemented whenever feasible (e.g. Abrantes et al., 2012; Fagan et al., 2011; Kiljunen et al., 2006; Logan et al., 2008; Mintenbeck et al., 2008).

The aim of this study was to evaluate the use of fish gills as a dietary tracer for various marine fish species from the Dutch Wadden Sea by determining and comparing the $\delta^{13} \mathrm{C}$ and $\delta^{15} \mathrm{~N}$ signal of gills with those of white muscle tissue. In addition, we investigate the effect of lipid content on the $\delta^{13} \mathrm{C}$ signal of gill and muscle tissue and assess the applicability of lipidcorrection models for gill tissue.

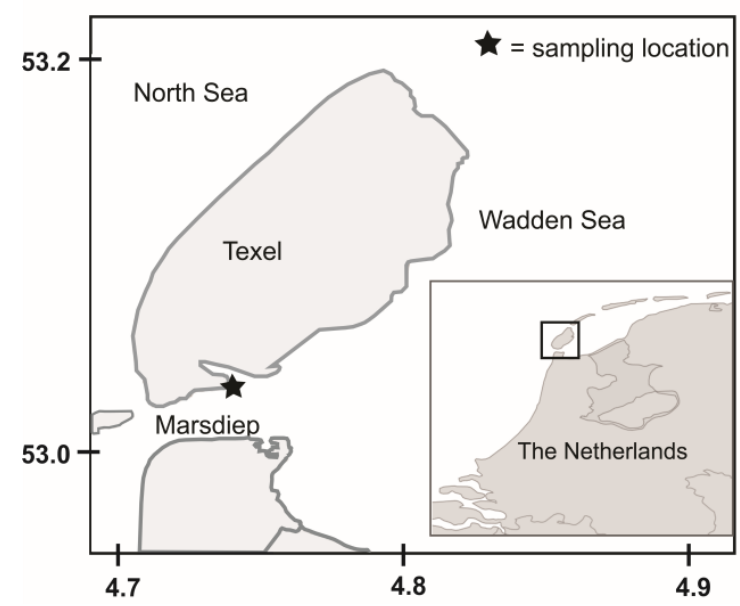

Figure 1 Location of the sampling area in the Marsdiep, western Dutch Wadden Sea.

\section{Methods}

\subsection{Sampling}

Fishes were collected using a passive fishing device (kom-fyke net; van der Veer et al., 2011) in the Marsdiep area, near the southern part of Texel (Netherlands), at the entrance to the western Dutch Wadden Sea (Figure 1), in spring (April to June) and autumn (September to October) 2011. Individuals were either processed or frozen immediately after capture. In the lab, all fish were measured to the nearest $\mathrm{cm}$ total length and weighed, and gill tissue and white muscle were sampled. Muscle tissue was taken from below the dorsal fin and cleaned from skin and scales. Tissue samples were subsequently frozen and freeze-dried for $72 \mathrm{~h}$ and stored in glass vials at $-20^{\circ} \mathrm{C}$ until analysis. Before lipid extraction and stable isotope analysis, samples were homogenized using a mortar and pestle or a ball mill grinder (Retsch MM400).

\subsection{Lipid extraction and quantification}

Lipids were extracted from gills and muscle tissue of a selected number of fishes.

Approximately $2 \mathrm{ml}$ dichloromethane/methanol $(2: 1, \mathrm{v} / \mathrm{v})$ was added to $8-50 \mathrm{mg}$ of freezedried muscle or gill tissue. The mixture was then sonicated for $10 \mathrm{~min}$, centrifuged ( $1000 \mathrm{xg}, 2.5$ $\mathrm{min})$, and the organic solvents pipetted off into a round-bottom flask. The extraction was repeated three additional times with sonication times of $5 \mathrm{~min}$. Extracted tissue and total lipid extracts (TLE) were evaporated to dryness under a stream of $\mathrm{N}_{2}$ at room temperature, weighed, and the lipid content calculated as weight percent of the non-extracted freezedried, tissue.

\subsection{Stable isotope analysis}

The stable nitrogen isotopic ratios $\left(\delta^{15} \mathrm{~N}\right)$ of fish muscle and gills were determined on bulk tissue, and the stable carbon isotopic ratios $\left(\delta^{13} \mathrm{C}\right)$ were determined on tissue before extraction $\left(\delta^{13} C_{\text {bulk }}\right)$, after extraction (extracted residue; $\delta^{13} C_{\text {extracted }}$ ) and on the total lipid extracts $\left(\delta^{13} \mathrm{C}_{\mathrm{TLE}}\right)$. Approximately $0.4-0.8 \mathrm{mg}$ of dry, homogenized sample (bulk and extracted residue) was weighed into tin cups. Total lipid extracts were dissolved in ethyl acetate and pipetted into the tin cups for a final weight of approx. $0.4 \mathrm{mg}$ for $\delta^{13} \mathrm{C}$ and $\delta^{15} \mathrm{~N}$ determination; ethyl acetate was allowed to evaporate completely at room temperature (minimum $6 \mathrm{~h}$ ) before folding the cups for analysis. Stable isotope analysis $\left(\delta^{13} \mathrm{C}, \delta^{15} \mathrm{~N}\right)$ and \%total organic carbon (\%TOC) and \%total nitrogen (\%TN) contents were determined in duplicate by isotope ratio monitoring mass spectrometry (irmMS) using a Delta $\mathrm{V}$ Advantage-irmMS coupled to a Flash 2000 elemental analyzer (Thermo Scientific). Stable isotope ratios are expressed using the $\delta$ notation in units per mil according to:

$\delta(\%)=\left(\left(R_{\text {sample }} / R_{\text {standard }}\right)-1\right) \times 1000, \quad[$ Equation 
where $R={ }^{13} \mathrm{C} /{ }^{12} \mathrm{C}$ or ${ }^{15} \mathrm{~N} /{ }^{14} \mathrm{~N}$

1]

and expressed versus Vienna Pee Dee Belemnite (VPDB) for $\delta^{13} \mathrm{C}$ and atmospheric $\mathrm{N}_{2}$ (air) for $\delta^{15} \mathrm{~N}$. A laboratory acetanilide standard with $\delta^{13} \mathrm{C}$ and $\delta^{15} \mathrm{~N}$ values calibrated against NBS-22 oil and IAEA-N1, respectively, and known \%TOC and \%TN content, was used for calibration. The average repeatability of $\delta^{13} \mathrm{C}$ determination was $0.18 \%$ o $(n=52)$ based on repeated analysis of the acetanilide standard over time.

\subsection{Data analysis and availability}

Paired Student's t-tests were used to compare treatments (bulk, lipid-extracted) and tissues (gill, muscle) using R, version 2.15.2 (R Core Team, 2012) in $R$ studio, version 0.97 .318 (RStudio, 2013). Results were evaluated at a 5\% significance level.

Data used in this study are available at http://doi.pangaea.de/10.1594/PANGAEA.8320 15

\section{Results and discussion}

Total organic carbon (\%TOC), total nitrogen

(\%TN), and stable isotope ratios of carbon $\left(\delta^{13} \mathrm{C}\right)$ and nitrogen $\left(\delta^{15} \mathrm{~N}\right)$ were measured in gill and white muscle tissue of 27 fish species (Table 1) and 128 individuals (Suppl. Table S1) caught in the Marsdiep at the entrance of the Dutch Wadden Sea (Figure 1). In addition, lipids were extracted from gill and muscle tissue of 14 individuals (three species; Table 2) in order to establish a lipid correction model which includes gill tissue, and to compare this to other published lipid correction models.

Overall, bulk $\delta^{13} \mathrm{C}$ and $\delta^{15} \mathrm{~N}$ values ranged from -25 to $-11 \%$ and 9 to $21 \%$, respectively, in both muscle and gill tissue, while bulk $\mathrm{C}: \mathrm{N}$ ratios $(\mathrm{w} / \mathrm{w})$ ranged from 3 to 6 in muscle tissue and 3 to 8 in gill tissue (Table 1). The average isotopic difference between muscle and gill tissue for the different fish species varied between 0.01$2.2 \%$ for $\delta^{13} \mathrm{C}$ and $0.1-2.4 \%$ for $\delta^{15} \mathrm{~N}$, though this difference varied greatly between individuals, ranging from -3 to $+3 \%$ and -2 to $3 \%$ for $\delta^{13} \mathrm{C}$ and $\delta^{15} \mathrm{~N}$, respectively (Suppl. Table $\mathrm{S} 1)$. The higher $\mathrm{C}: \mathrm{N}$ ratios of gill tissue (average
4.0) compared to muscle tissue (average 3.3) suggest a higher lipid content in these samples. As the influence of lipids on the $\delta^{13} \mathrm{C}$ signal is well known (DeNiro and Epstein, 1977; Monson and Hayes, 1982), the observed differences in $\delta^{13} \mathrm{C}$ between muscle and gill may therefore be due to a high content of ${ }^{13} \mathrm{C}$ depleted lipids in the gills.

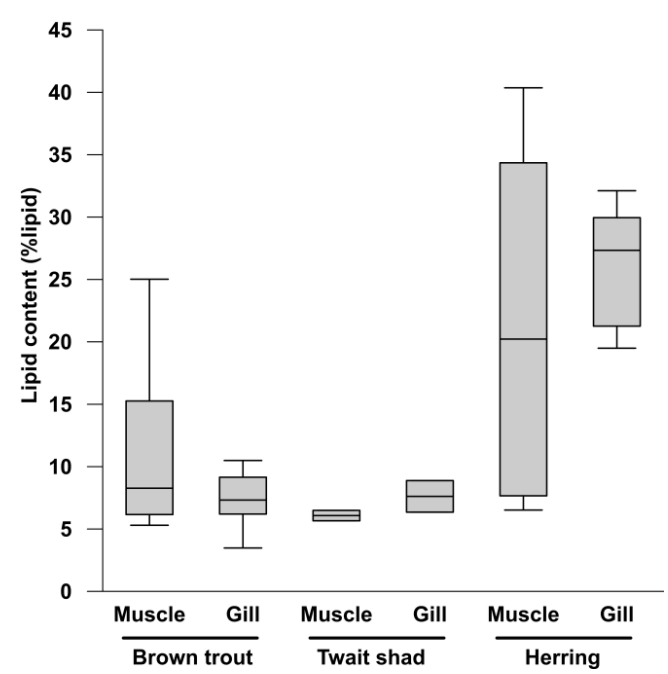

Figure 2 Lipid content (\%lipid) of brown trout (C. harengus, $n=6)$, Twait shad (A. fallax, $n=2$ ), and Atlantic herring ( $C$. harengus, $\mathrm{n}=6$ ). Boxes show minimum, maximum, and median values, and bars the $1^{\text {st }}$ and $3^{\text {rd }}$ quartiles for each species.

\subsection{Impact of lipid content on $\delta^{13} \mathrm{C}$ of fish tissue}

To determine the effect of lipid content on the $\delta^{13} \mathrm{C}$ values of fish gills, lipids were extracted from both gills and white muscle tissue from three fish species: brown trout (Salmo trutta), twait shad (Alosa fallax), and Atlantic herring (Clupea harengus), and the $\delta^{13} \mathrm{C}$ values of bulk tissue $\left(\delta^{13} C_{\text {bulk }}\right)$, extracted tissue $\left(\delta^{13} C_{\text {extracted }}\right)$ and total lipid extract $\left(\delta^{13} \mathrm{C}_{\mathrm{TLE}}\right)$ were determined (Table 2). These species were chosen based on sample availability and to cover as large as possible range of C:N values (Table 1 ).

Lipid content in muscle and gill tissues ranged between $5-40 \%$ and $3-32 \%$, respectively (Table 2 ) and was highly variable, especially in muscle and gill tissue of Atlantic herring and in muscle from brown trout (Figure 2). In addition to large 
Table 1 Average of bulk $\delta^{13} \mathrm{C}$ and $\delta^{15} \mathrm{~N}$ values and C: $\mathrm{N}$ ratios in muscle and gill tissue of the various fish species. $n=$ number of specimens.

\begin{tabular}{|c|c|c|c|c|c|c|c|}
\hline \multirow[b]{2}{*}{ Species } & \multirow[b]{2}{*}{$\mathbf{n}$} & \multicolumn{3}{|c|}{ MUSCLE } & \multicolumn{3}{|c|}{ GILL } \\
\hline & & $\delta^{13} \mathrm{C}$ & $\delta^{15} \mathrm{~N}$ & $C: N$ & $\delta^{13} \mathrm{C}$ & $\delta^{15} N$ & $C: N$ \\
\hline Alosa fallax & 7 & $-20.6 \pm 2.5$ & $15.5 \pm 1.3$ & $3.2 \pm 0.1$ & $-20.6 \pm 2.5$ & $14.3 \pm 1.4$ & $4.2 \pm 0.5$ \\
\hline Ammodytes tobianus & 5 & $-17.3 \pm 0.4$ & $14.9 \pm 0.5$ & $3.2 \pm 0.1$ & $-18.2 \pm 1.1$ & $14.6 \pm 0.8$ & $4.4 \pm 0.8$ \\
\hline Arnoglossus laterna & 1 & -17.6 & 16.5 & 3.2 & -16.8 & 15.6 & 3.3 \\
\hline Atherina presbyter & 1 & -15.8 & 15.6 & 3.2 & -15.3 & 15.0 & 3.4 \\
\hline Belone belone & 3 & $-17.6 \pm 0.7$ & $14.6 \pm 1.7$ & $3.1 \pm 0.1$ & $-18.0 \pm 0.9$ & $14.4 \pm 1.0$ & $3.7 \pm 0.2$ \\
\hline Chelon labrosus & 2 & $-11.2 \pm 0.9$ & $11.5 \pm 3.2$ & $3.3 \pm 0.0$ & $-11.2 \pm 0.8$ & $12.5 \pm 1.9$ & $3.6 \pm 0.1$ \\
\hline Clupea harengus & 20 & $-18.6 \pm 2.2$ & $13.9 \pm 1.4$ & $3.6 \pm 1.0$ & $-19.7 \pm 2.2$ & $13.1 \pm 1.4$ & $5.1 \pm 1.1$ \\
\hline Dicentrarchus labrax & 13 & $-16.2 \pm 1.8$ & $16.6 \pm 0.9$ & $3.3 \pm 0.1$ & $-16.5 \pm 1.7$ & $15.6 \pm 1.3$ & $3.7 \pm 0.3$ \\
\hline Engraulis encrasicolus & 1 & -18.5 & 13.8 & 3.3 & -20.6 & 11.4 & 5.1 \\
\hline Gasterosteus aculeatus & 1 & -21.9 & 15.4 & 5.0 & -22.2 & 15.1 & 5.7 \\
\hline Hyperoplus lanceolatus & 1 & -17.4 & 14.0 & 3.9 & -19.7 & 13.1 & 3.6 \\
\hline Liza aurata & 1 & -24.3 & 20.8 & 3.9 & -24.0 & 19.4 & NA \\
\hline Merlangius merlangus & 2 & $-17.3 \pm 0.3$ & $15.5 \pm 0.8$ & $3.2 \pm 0.1$ & $-16.6 \pm 0.5$ & $15.1 \pm 0.1$ & $3.4 \pm 0.2$ \\
\hline Osmerus eperlanus & 3 & $-16.4 \pm 0.4$ & $16.5 \pm 0.5$ & $3.1 \pm 0.0$ & $-18.3 \pm 0.8$ & $15.0 \pm 0.1$ & $4.8 \pm 1.0$ \\
\hline Platichthys flesus & 17 & $-17.1 \pm 2.8$ & $15.8 \pm 0.6$ & $3.2 \pm 0.1$ & $-17.0 \pm 2.7$ & $15.1 \pm 0.5$ & $3.7 \pm 0.2$ \\
\hline Pleuronectes platessa & 10 & $-15.9 \pm 1.0$ & $14.1 \pm 1.0$ & $3.2 \pm 0.1$ & $-16.0 \pm 1.2$ & $13.2 \pm 1.1$ & $3.6 \pm 0.1$ \\
\hline Pollachius pollachius & 1 & -16.6 & 16.3 & 3.1 & -17.1 & 15.6 & 3.7 \\
\hline Raniceps raninus & 1 & -16.7 & 18.5 & 3.2 & -16.5 & 17.7 & 3.6 \\
\hline Salmo trutta & 13 & $-20.1 \pm 2.1$ & $15.1 \pm 1.4$ & $3.4 \pm 0.4$ & $-19.0 \pm 1.8$ & $15.3 \pm 1.1$ & $3.8 \pm 0.1$ \\
\hline Scomber scombrus & 1 & -18.8 & 10.6 & 3.1 & -18.3 & 10.5 & 3.6 \\
\hline Scophthalmus maximus & 3 & $-16.4 \pm 0.2$ & $15.4 \pm 0.3$ & $3.2 \pm 0.1$ & $-16.0 \pm 0.1$ & $15.2 \pm 0.1$ & $3.6 \pm 0.0$ \\
\hline Scophthalmus rhombus & 1 & -16.8 & 16.9 & 3.1 & -18.2 & 16.2 & 4.4 \\
\hline Solea solea & 2 & $-17.4 \pm 1.1$ & $15.3 \pm 0.7$ & $3.2 \pm 0.0$ & $-16.9 \pm 0.2$ & $15.5 \pm 0.4$ & $3.6 \pm 0.0$ \\
\hline Sprattus sprattus & 6 & $-18.1 \pm 0.6$ & $14.2 \pm 0.9$ & $3.3 \pm 0.3$ & $-19.2 \pm 1.1$ & $13.8 \pm 0.8$ & $4.7 \pm 1.1$ \\
\hline Syngnathus acus & 1 & -17.7 & 13.3 & 3.2 & -17.0 & 14.4 & 2.7 \\
\hline Trachurus trachurus & 2 & $-16.8 \pm 0.2$ & $14.9 \pm 1.0$ & $3.2 \pm 0.1$ & $-17.6 \pm 0.9$ & $13.9 \pm 0.3$ & $3.6 \pm 0.0$ \\
\hline Trisopterus Iuscus & 9 & $-16.8 \pm 0.5$ & $14.9 \pm 0.4$ & $3.2 \pm 0.1$ & $-16.3 \pm 1.0$ & $14.3 \pm 1.0$ & $3.6 \pm 0.3$ \\
\hline
\end{tabular}

variations in \%lipid between samples, Atlantic herring also had the highest median \%lipid in both tissue types, with 20 and 27\%, respectively. The median \%lipid for brown trout and twait shad were much lower and ranged from 6 to $8 \%$.

Total lipid extracts were, as expected based on biosynthetic fractionation during lipid synthesis (DeNiro and Epstein, 1977; Monson and Hayes,1982), depleted in ${ }^{13} \mathrm{C}$ compared to bulk tissue by $3.7-5.8 \%$ (Table 2). Removal of this ${ }^{13} \mathrm{C}$-depleted material resulted in extracted tissue enriched in ${ }^{13} \mathrm{C}$ by $0.2-2.6 \%$ in muscle and $2.1-4.3 \%$ in gill, respectively, compared to bulk tissue (Table 2). The lipid content was positively correlated to both the $\mathrm{C}: \mathrm{N}$ ratio of bulk biomass and the difference in $\delta^{13} \mathrm{C}$ before and after extraction $\left(\Delta \delta^{13} C_{\text {(extracted-bulk) }}\right)$ for both tissue types (Figure 3 ). The $\mathrm{C}: \mathrm{N}$ ratio of bulk biomass was also correlated to $\Delta \delta^{13} C_{\text {(extracted-bulk) }}$ $\left(R^{2}=0.90\right.$, Figure 4). These results unambiguously showed that lipid content has a substantial effect on the $\delta^{13} C_{\text {bulk }}$ values of muscle and gills of Wadden Sea fish. 
Table 2 Lipid content (\%lipid), C:N ratios and $\delta^{13} \mathrm{C}$ values of bulk samples, extracted tissue and the lipid fraction (TLE). $d w=d r y$ weight. Standard deviations of duplicate isotope analyses were $\leq 0.3$.

\begin{tabular}{|c|c|c|c|c|c|c|c|}
\hline \multirow{2}{*}{ Species } & & \multirow{2}{*}{$\begin{array}{l}\text { Lipids } \\
\text { (\%dw) }\end{array}$} & \multicolumn{2}{|c|}{ C:N } & \multicolumn{3}{|c|}{$\delta^{13} \mathrm{C}$} \\
\hline & & & bulk & extracted & bulk & extracted & TLE \\
\hline \multirow{2}{*}{ S. trutta } & Muscle & 25 & 5.0 & 3.1 & -20.2 & -17.6 & -24.8 \\
\hline & Gill & 10 & 3.9 & 3.2 & -17.9 & -16.6 & -23.7 \\
\hline \multirow{2}{*}{ S. trutta } & Muscle & 5 & 3.2 & 3.0 & -23.0 & -22.8 & n.d. \\
\hline & Gill & 8 & 3.8 & 3.1 & -20.1 & -19.7 & -23.8 \\
\hline \multirow{2}{*}{ S. trutta } & Muscle & 9 & 3.3 & 3.2 & -18.1 & -17.7 & -23.6 \\
\hline & Gill & 9 & 3.8 & 3.3 & -18.0 & -16.8 & -23.8 \\
\hline \multirow{2}{*}{ S. trutta } & Muscle & 6 & 3.2 & 3.1 & -18.9 & -18.5 & -24.4 \\
\hline & Gill & 6 & 4.0 & 3.5 & -19.5 & -18.6 & -25.5 \\
\hline \multirow{2}{*}{ S. trutta } & Muscle & 8 & 3.3 & 3.1 & -19.2 & -18.8 & -24.5 \\
\hline & Gill & 3 & 3.7 & 3.2 & -17.2 & -16.4 & -24.5 \\
\hline \multirow{2}{*}{ S. trutta } & Muscle & 15 & 4.0 & 3.0 & -18.6 & -17.3 & -24.3 \\
\hline & Gill & 7 & 3.8 & 3.2 & -17.6 & -16.7 & -23.4 \\
\hline \multirow{2}{*}{ A. fallax } & Muscle & 6 & 3.2 & 3.1 & -17.3 & -16.5 & -22.8 \\
\hline & Gill & 9 & 4.2 & 3.3 & -17.3 & -15.4 & -23.1 \\
\hline \multirow{2}{*}{ A. fallax } & Muscle & 6 & 3.2 & 3.1 & -22.3 & -22.1 & n.d. \\
\hline & Gill & 6 & 4.3 & 3.6 & -22.4 & -21.2 & n.d. \\
\hline \multirow{2}{*}{ C. harengus } & Muscle & 8 & 3.4 & 3.1 & -19.6 & -19.1 & -25.4 \\
\hline & Gill & 30 & 5.6 & 3.3 & -22.4 & -19.7 & -26.9 \\
\hline \multirow{2}{*}{ C. harengus } & Muscle & 34 & 6.1 & 3.1 & -22.9 & -20.5 & -26.0 \\
\hline & Gill & 32 & 8.0 & 3.2 & -23.1 & -19.1 & -26.2 \\
\hline \multirow{2}{*}{ C. harengus } & Muscle & 8 & 3.3 & 3.0 & -18.0 & -17.5 & -24.3 \\
\hline & Gill & 25 & 5.9 & 3.2 & -19.7 & -16.8 & -23.4 \\
\hline \multirow{2}{*}{ C. harengus } & Muscle & 32 & 5.8 & 3.1 & -23.0 & -20.7 & -25.9 \\
\hline & Gill & 19 & 4.8 & 3.3 & -21.7 & -19.2 & -26.3 \\
\hline \multirow{2}{*}{ C. harengus } & Muscle & 40 & 5.8 & 3.1 & -23.6 & -21.0 & -26.7 \\
\hline & Gill & 30 & 6.0 & 3.0 & -23.2 & -19.6 & -27.0 \\
\hline \multirow{2}{*}{ C. harengus } & Muscle & 7 & 3.3 & 3.0 & -20.2 & -19.8 & -26.8 \\
\hline & Gill & 21 & 6.6 & 3.1 & -23.3 & -19.0 & -27.8 \\
\hline
\end{tabular}

n.d. Not determined because of not enough material/area too low for reliable measurement

The strong correlations of both $\Delta \delta^{13} \mathrm{C}_{\text {(extracted- }}$ bulk) and \%lipid with bulk biomass $\mathrm{C}: \mathrm{N}$ ratio allows us to construct a lipid correction model based on the ${ }^{13} \mathrm{C}$ content and the bulk $\mathrm{C}: \mathrm{N}$ ratio (muscle and gills; Equation 2):

$\delta^{13} C_{\text {corr }}=\delta^{13} C_{\text {bulk }}-2.45+0.90 \times C: N, \quad(n=28$, $\mathrm{R}^{2}=0.90, \mathrm{SE}=0.4 \%$ ) [Equation 2]

To determine the effect of tissue type on the correlation in Equation 2, corresponding equations were also constructed separately for gill (Equation 3) and muscle (Equation 4) tissue:

Muscle: $\quad \delta^{13} C_{\text {corr }}=\delta^{13} C_{\text {bulk }}-2.21+0.82 \times C: N$ $\left(n=14, R^{2}=0.97, S E=0.3\right) \quad$ [Equation 3]

Gills: $\quad \delta^{13} \mathrm{C}_{\text {corr }}=\delta^{13} \mathrm{C}_{\text {bulk }}-2.41+0.92 \times \mathrm{C}: \mathrm{N}$ $\left(n=14, R^{2}=0.80, S E=0.5\right) \quad$ [Equation 4] 

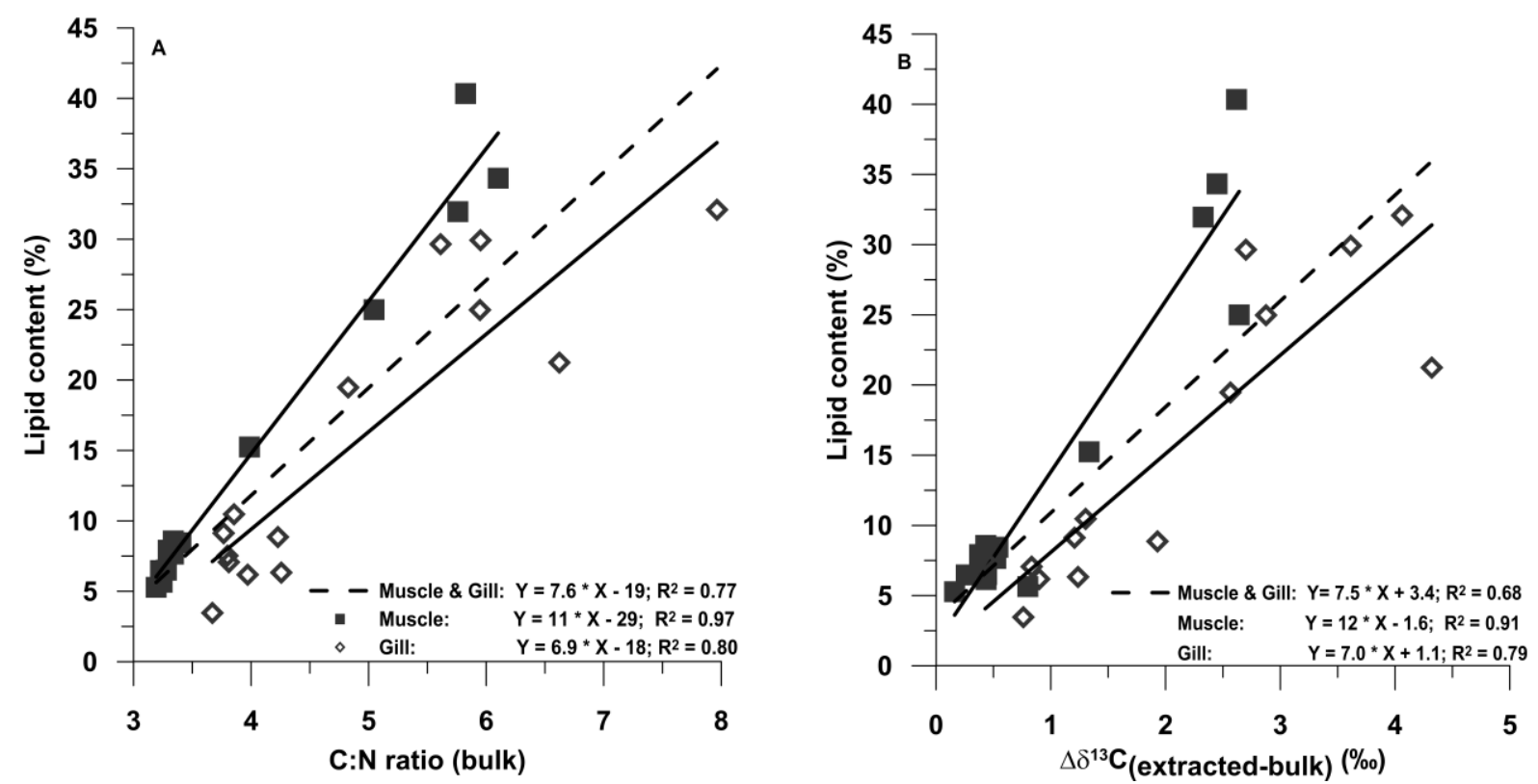

Figure 3 Correlation between lipid content (\%lipid) and A) the C:N ratio of bulk biomass and $B$ ) the difference in $\delta^{13} \mathrm{C}$ before and after extraction $\left(\Delta \delta^{13} C_{\text {(extracted-bulk) })}\right.$.

A paired t-test was used to evaluate calculated $\delta^{13} C$ values $\left(\delta^{13} C_{(\text {corrected })}\right)$, using either the combined muscle and gill data set (Equation 2) or tissue-specific data sets (Equations 3 and 4). Although there was a statistically significant difference $(p<0.05)$ in corrected $\delta^{13} \mathrm{C}$ values obtained with the different equations, the average difference $(<0.1$ and $0.02 \%$ for muscle and gill, respectively), was smaller than the instrumental error $(0.2 \%)$. Therefore, it is reasonable to use the non-tissue specific correction for both tissue types. Logan et al (2008) found a best fit over a wide range of C:N values (2.5 to 12.5 ) using a non-linear model $\left(\Delta \delta^{13} C=\beta_{0}+\beta_{1} \times \ln C: N\right)$. In this study, however,
$\mathrm{C}: \mathrm{N}$ ratios were $<8$ and although the coefficient of determination $\left(R^{2}\right)$ was slightly higher for using a logarithmic curve compared to a linear curve (0.92 vs 0.90$)$, there was no significant difference in corrected $\delta^{13} \mathrm{C}$ values for the two methods compared to $\delta^{13} \mathrm{C}$ values of extracted tissue (paired t-test, $p<0.05$; Table 3 ).

Application of our lipid correction model (Equation 2) to measured bulk $\delta^{13} \mathrm{C}$ values (Suppl. Table S1) yielded $\delta^{13} \mathrm{C}$ values statistically identical (paired t-test) to $\delta^{13} \mathrm{C}$ values of extracted tissue. In contrast, application of the correction models published by McConnaughey and McRoy (1979) for high latitude animals,

Table 3 Comparison of $\delta^{13} \mathrm{C}$ values in lipid extracted tissue with $\delta^{13} \mathrm{C}$ values calculated using different lipid correction models (Paired t-test, $\alpha=0.05$ ).

\begin{tabular}{llcc} 
& Equation & $\mathbf{R}^{2}$ & $\mathbf{p}$ \\
\hline Linear (this study) & $\Delta \delta^{13} \mathrm{C}=-2.45+0.90 \times \mathrm{C}: \mathrm{N}$ & 0.90 & $\mathrm{n} . \mathrm{s}$. \\
Exponential (this study) & $\Delta \delta^{13} \mathrm{C}=-4.8+4.4 \times \ln (\mathrm{C}: \mathrm{N})$ & 0.92 & n.s. \\
\hline & $\mathrm{L}=93 /(1+(0.246 \times \mathrm{C}: \mathrm{N}-0.775)-1)^{*}$ & $<0.001$ \\
McConnaughey and McRoy, 1979 & $\Delta \delta^{13} \mathrm{C}=\mathrm{D} \times(-0.207+(3.90 /(1+287 / \mathrm{L})))^{* *}$ & \\
& $\Delta \delta^{13} \mathrm{C}=-3.2+0.99 \times \mathrm{C}: \mathrm{N}$ & 0.91 & $<0.001$ \\
& $\Delta \delta^{13} \mathrm{C}=-2.98+3.09 \times \ln (\mathrm{C}: \mathrm{N})$ & 0.93 & $\mathrm{n} . \mathrm{s}$ \\
Post et al. 2007 & $\Delta \delta^{13} \mathrm{C}=-1.87+0.65 \times \mathrm{C}: \mathrm{N}$ & 0.92 & $<0.001$ \\
Logan et al. 2008 & & \\
Abrantes et al. 2012 & &
\end{tabular}


Post et al (2007) for aquatic animals, and Abrantes et al (2012) for salmonid muscle tissue, showed that there was a significant difference in the $\delta^{13} \mathrm{C}$ values of lipid extracted tissue and corrected $\delta^{13} \mathrm{C}$ values (paired t-tests $\mathrm{p}<0.001$, Table 3 ). The non-linear model from Logan et al. (2008), however, resulted in a high correlation $\left(R^{2}=0.93\right)$ and $\delta^{13} C_{\text {corr }}$ values that were not significantly different from measured $\delta^{13} \mathrm{C}$ in extracted tissues ( $p<0.55$; Table 3 ). Overall, our results confirm those of other studies (Abrantes et al., 2012; Fagan et al., 2011; Logan et al., 2008) which demonstrate that in cases of high or highly variable lipid content, a lipid correction model should be constructed through extraction of a sample subset. Comparison of $\delta^{13} \mathrm{C}_{\text {corr }}$ and $\delta^{15} \mathrm{~N}$ values in gill and muscle tissue.

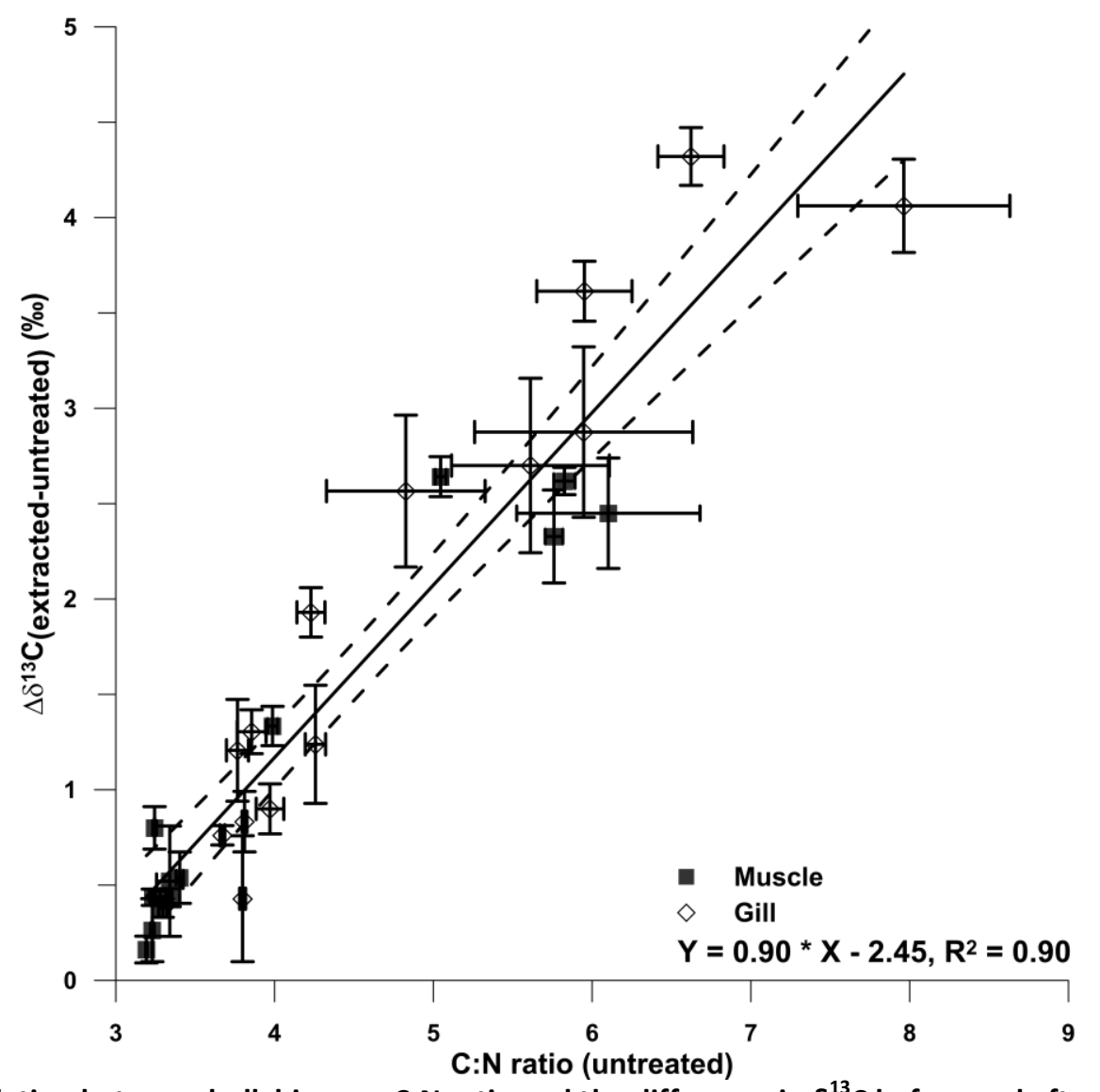

Figure 4 Correlation between bulk biomass $\mathrm{C}: \mathrm{N}$ ratio and the difference in $\delta^{13} \mathrm{C}$ before and after extraction $\left(\Delta \delta^{13} C_{(\text {extracted-bulk) }}\right)$. Error bars indicate standard devation of replicates.

\subsubsection{Lipid corrected $\delta^{13} \mathrm{C}$ values in muscle and gill tissue}

To determine if the $\delta^{13} \mathrm{C}_{\text {bulk }}$ of muscle and gill tissue record different $\delta^{13} \mathrm{C}$ signals we applied the lipid correction model from this study (Equation 2) to the bulk $\delta^{13} \mathrm{C}$ values of the entire data set (Suppl. Table S1). A plot of gill vs. muscle $\delta^{13} \mathrm{C}$ values of all species shows that isotopic ratios of the two tissues are highly correlated $\left(R^{2}=0.85\right)$ over a large isotopic range, with a minor, non-significant, offset from the 1:1 line, with gill tissue being slightly more enriched in ${ }^{13} \mathrm{C}$ (Figure 5B). The similarity in $\delta^{13} \mathrm{C}$ signals suggests that fish gills generally record the same long-term $\delta^{13} \mathrm{C}$ signal as white muscle tissue. Only for the species Platichthys flesus, Pleuronectes platessa, Salmo trutta, and Trisopterus luscus was there a small, though statistically significant, difference of $0.3-1.3 \%$ in the $\delta^{13} \mathrm{C}$ of muscle and gill tissue $(p<0.05)$, with muscle tissue generally having a more negative $\delta^{13} \mathrm{C}$ signal than gill tissue (Figure $5 \mathrm{~A}$ ). We found no consistent pattern or correlation with parameters such as size or date of capture and the isotopic offset for these four species. In the case of $S$. trutta, an anadromous species exhibiting river to estuary or sea migrations (Elliott, 1994), the difference in the isotopic 
ratio could indicate that muscle tissue captures a more freshwater origin, whereas gills may reflect the sea-run phase with rapid growth and building up for reproduction (de Leeuw et al., 2007). For the other species, which are typically
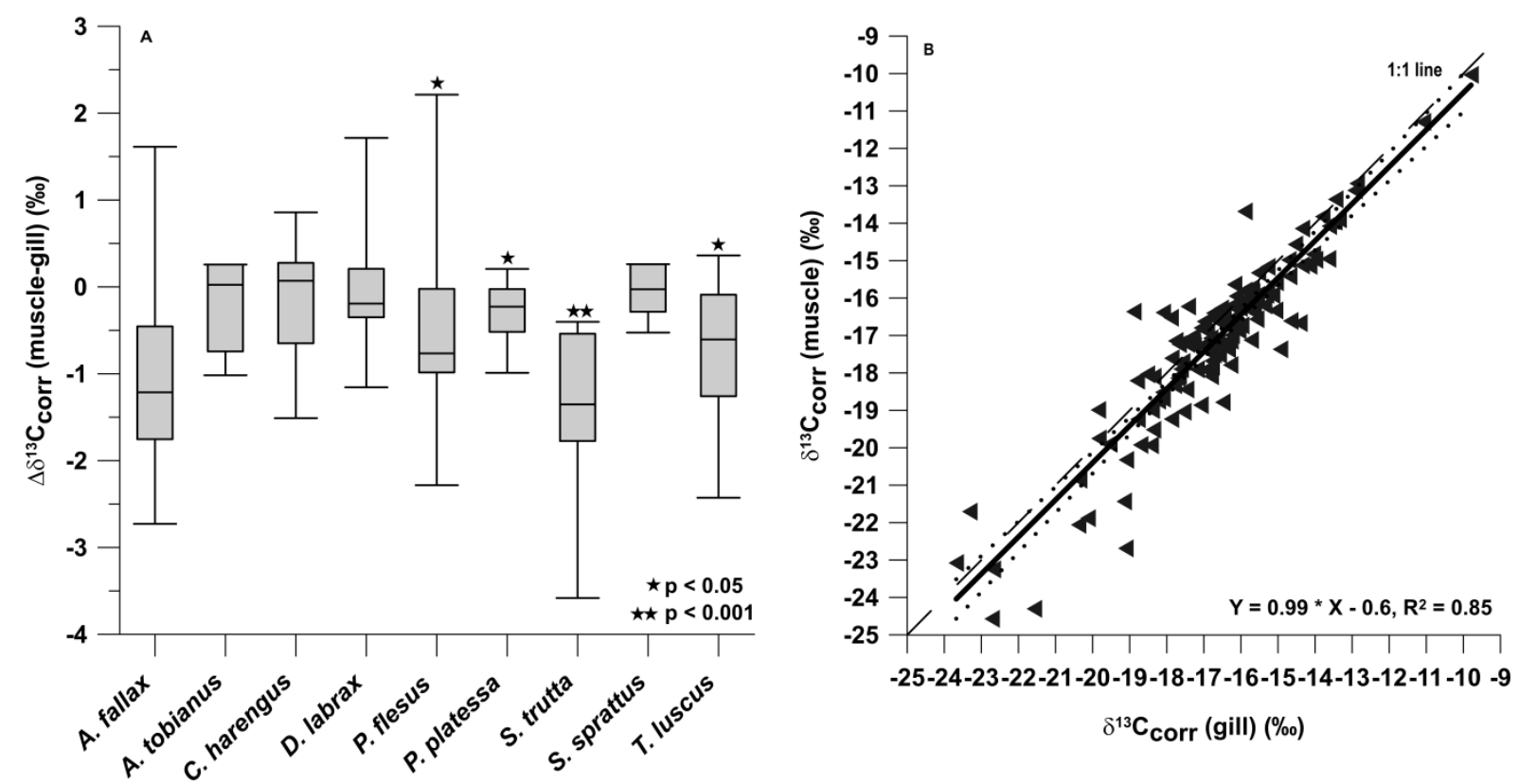

Figure $5 \mathrm{~A}$ ) Difference in corrected $\delta^{13} \mathrm{C}$ values $\left(\Delta \delta^{13} \mathrm{C}_{(\text {gill-muscle) }}\right)$ between muscle and gill tissue after lipid correction using Equation 2. Boxes show minimum, maximum, and median values, and bars the $1^{\text {st }}$ and $3^{\text {rd }}$ quartiles for each species $(n \geq 5)$. B) Correlation between $\delta^{13} c_{\text {(corr) }}$ of muscle and gill tissue of the whole data set (Suppl. Table S1). The dashed line indicates a 1:1 curve, and dotted lines the $95 \%$ confidence interval.

marine, this may not apply and differences may be due to tissue-specific ${ }^{13} \mathrm{C}$ fractionation and turnover rates.

\subsection{2 $\quad \delta^{15} \mathrm{~N}$ in muscle and gill tissue}

A comparison of $\delta^{15} \mathrm{~N}$ values of muscle and gill tissue $\left(\Delta \delta^{15} \mathrm{~N}_{\text {(muscle-gill) }}\right)$ showed that muscle tissue five out of nine species (species average difference 0.7-1.2\%o; Figure 6A). As with the $\delta^{13} \mathrm{C}$ values, we found a strong linear relationship between $\delta^{15} \mathrm{~N}_{\text {muscle }}$ and $\delta^{15} \mathrm{~N}_{\text {gill }}$ $\left(R^{2}=0.76\right.$, Figure $\left.6 B\right)$ over a large isotopic range though there was an offset from the 1:1 line with muscle tissue being more enriched in the heavier ${ }^{15} \mathrm{~N}$ isotope, especially at lower $\delta^{15} \mathrm{~N}$ values (Figure 6B). The reason for this is not clear, but may be related to compositional differences in amino acids (AAs) in the two tissue types (e.g. Willis et al., 2013; Wolf et al., 2009) as different AAs can have widely different isotopic compositions caused by different metabolic pathways (Chikaraishi et al., 2009, 2007; McCarthy et al., 2007; McClelland et al., generally was more enriched in ${ }^{15} \mathrm{~N}$ compared to gill tissue for most species (Table 1). This is in accordance with results reported by Banas et al. (2009), who found higher $\delta^{15} \mathrm{~N}$ values in muscle compared to gill tissue in perch Perca fluviatilis during a controlled-feeding experiment. The difference was statistically significant $(p<0.05)$ in

2003). Alternatively, these differences could be due to differences in isotopic turnover time between gill and muscle tissue. In a recent study, Xia et al. (2013) found that muscle tissue of freshwater grass carp (Ctenopharyngodon idellus) had a lower turnover rate of nitrogen isotopes than gills, with isotopic turnover times of $\sim 68$ vs. $\sim 115$ days, respectively. Finally, fish gills are complex structures, whose composition includes skeletal and smooth muscle, blood vessels and bone (Ostrander, 2000). Although the gill arch bone was removed during sample preparation, the tissues may still have contained some bone remains. This could have an impact on the results as the bone isotopic composition reflects dietary integration over longer time 
periods (Dalerum and Angerbjörn, 2005; Miller et al., 2010). Interestingly, an archaeological study comparing fish muscle-bone isotopic signatures reported similar trends as the ones

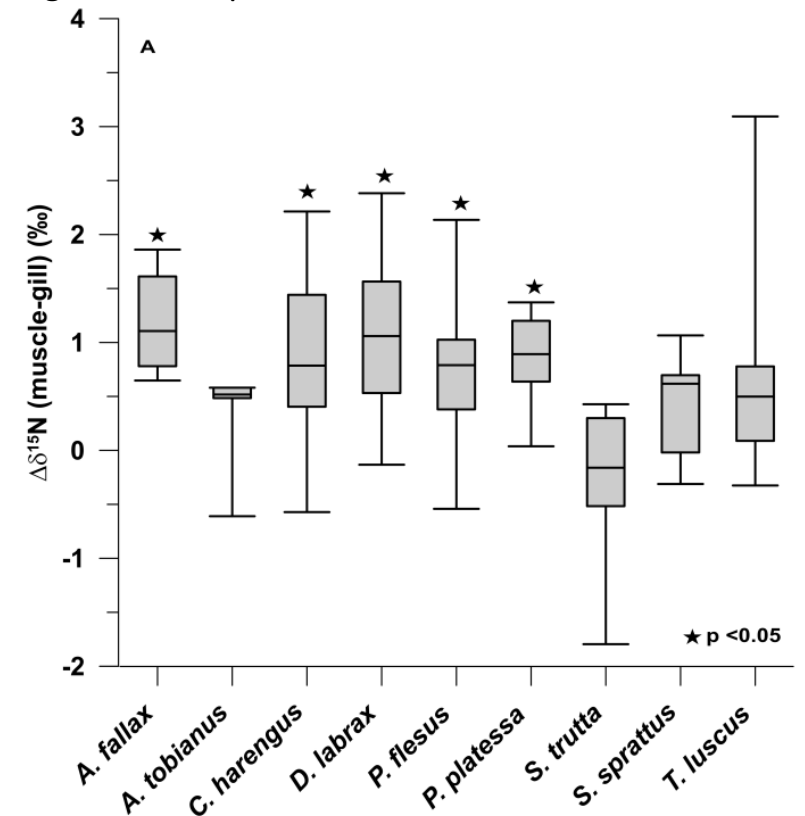

found here with bone being more enriched in $\delta^{13} \mathrm{C}$ but less enriched in $\delta^{15} \mathrm{~N}$ compared to muscle (Miller et al., 2010).

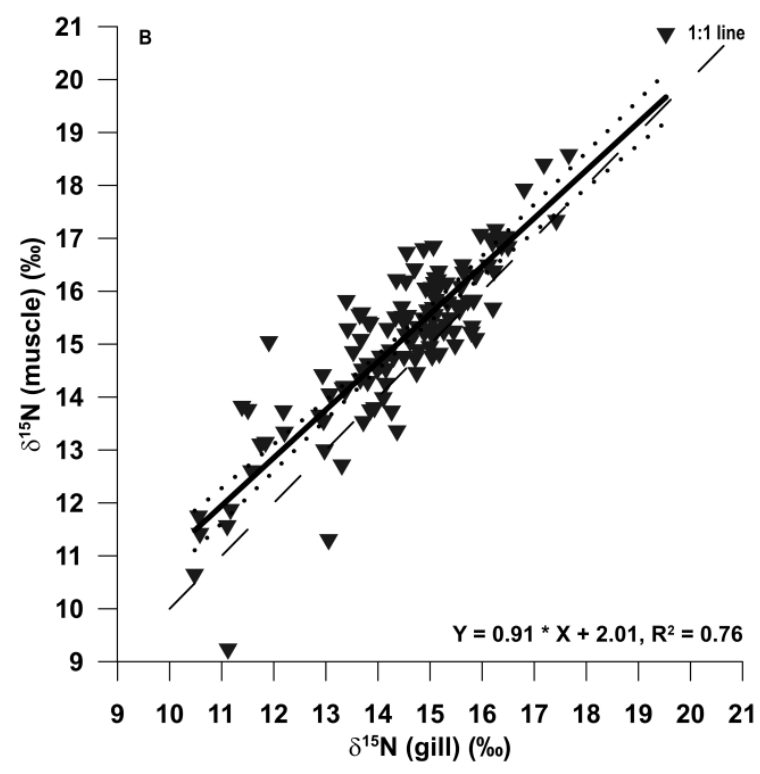

Figure 6 A) Difference in corrected $\delta^{15} \mathrm{~N}$ values $\left(\Delta \delta^{15} \mathrm{~N}_{\text {(gill-muscle) }}\right)$ between muscle and gill tissue after lipid correction using Equation 2. Boxes show minimum, maximum, and median values, and bars the $1^{\text {st }}$ and $3^{\text {rd }}$ quartiles for each species $(n \geq 5)$. B) Correlation between $\delta^{15} \mathrm{~N}$ of muscle and gill tissue of the whole data set (Suppl. Table S1). The dashed line indicates a 1:1 curve, and dotted lines the $95 \%$ confidence interval

\section{Conclusions}

Stable carbon and nitrogen isotope values were determined for gill and muscle tissue of a large number of fish species caught in the Dutch Wadden Sea. A comparison of the two tissue types showed an increase in the difference in $\delta^{13} \mathrm{C}$ between gill and muscle tissue with increasing $\mathrm{C}: \mathrm{N}$ ratios caused by a variable lipid content. A study-specific lipid correction model based on the $\delta^{13} \mathrm{C}$ and $\mathrm{C}: \mathrm{N}$ ratio of bulk material was developed. After lipid correction, no differences were observed in $\delta^{13} \mathrm{C}$ values of paired muscle and gill tissue for most species. For several species, a small, but statistically significant, difference between gill and muscle tissue was recorded, with gill tissue generally having slightly higher $\delta^{13} \mathrm{C}$ values than muscle tissue. Our results suggest that the $\delta^{13} \mathrm{C}$ value of fish gill tissue records similar food source signals as those of muscle tissue and that the two tissue types therefore can be used to determine shifts in diet or habitat in fish
Differences in $\delta^{15} \mathrm{~N}$ values of muscle and gill tissue were larger, and found to be significant in five out of nine species. Although a strong correlation between muscle and gill $\delta^{15} \mathrm{~N}$ values was observed, it is skewed towards higher ${ }^{15} \mathrm{~N}$ content in muscle tissue at lower $\delta^{15} \mathrm{~N}$ values. This may be due to preferential uptake of certain amino acids into different tissues or different isotopic turnover times of the tissues.

\section{Acknowledgements}

We would like to thank the anonymous reviewer for help with improving this manuscript. This work is part of the Waddensleutels project (http://www.waddensleutels.nl/) and supported by the Waddenfonds. V. Freitas was partly funded by Fundação para a Ciência e a Tecnologia (FCT, Portugal) and Fundo Social Europeu (POPH/FSE) (grant $\mathrm{nr}$. SFRH/BPD/75858/2011). 


\section{References}

Abrantes, K., Semmens, J., Lyle, J., Nichols, P., 2012. Normalisation models for accounting for fat content in stable isotope measurements in salmonid muscle tissue. Mar. Biol. 159, 57-64.

Banas, D., Vollaire, Y., Danger, M., Thomas, M., Oliveira-Ribeiro, C.A., Roche, H., Ledore, Y., 2009. Can we use stable isotopes for ecotoxicological studies? Effect of DDT on isotopic fractionation in Perca fluviatilis. Chemosphere 76, 734-739.

Bodin, N., Le Loc'h, F., Hily, C., 2007. Effect of lipid removal on carbon and nitrogen stable isotope ratios in crustacean tissues. J. Exp. Mar. Biol. Ecol. 341, 168-175.

Boecklen, W.J., Yarnes, C.T., Cook, B.A., James, A.C., 2011. On the use of stable isotopes in trophic ecology. Annu. Rev. Ecol. Evol. Syst. 42, 411-440.

Buchheister, A., Latour, R.J., 2010. Turnover and fractionation of carbon and nitrogen stable isotopes in tissues of a migratory coastal predator, summer flounder (Paralichthys dentatus). Can. J. Fish. Aquat. Sci. 67, 445-461.

Chikaraishi, Y., Kashiyama, Y., Ogawa, N.O., Kitazato, H., Ohkouchi, N., 2007. Metabolic control of nitrogen isotope composition of amino acids in macroalgae and gastropods: implications for aquatic food web studies. Mar. Ecol. Prog. Ser. 342, 85-90.

Chikaraishi, Y., Ogawa, N.O., Kashiyama, Y., Takano, Y., Suga, H., Tomitani, A., Miyashita, H., Kitazato, H., Ohkouchi, N., 2009. Determination of aquatic food-web structure based on compound-specific nitrogen isotopic composition of amino acids. Limnol. Oceanogr. Methods 7, 740-750.

Dalerum, F., Angerbjörn, A., 2005. Resolving temporal variation in vertebrate diets using naturally occurring stable isotopes. Oecologia 144, 647-658.

De Leeuw, J.J., ter Hofstede, R., Winter, H.V., 2007. Sea growth of anadromous brown trout (Salmo trutta). J. Sea Res. 58, 163-165.

DeNiro, M.J., Epstein, S., 1977. Mechanism of carbon isotope fractionation associated with lipid synthesis. Science 197, 261-263.

DeNiro, M.J., Epstein, S., 1978. Influence of diet on the distribution of carbon isotopes in animals. Geochim. Cosmochim. Acta 42, 495506.

DeNiro, M.J., Epstein, S., 1981. Influence of diet on the distribution of nitrogen isotopes in animals. Geochim. Cosmochim. Acta 45, 341351.

Ehrich, D., Tarroux, A., Stien, J., Lecomte, N., Killengreen, S., Berteaux, D., Yoccoz, N.G., 2011. Stable isotope analysis: modelling lipid normalization for muscle and eggs from arctic mammals and birds. Methods Ecol. Evol. 2, 66-76.

Elliott, J.M., 1994. Quantitative ecology and the brown trout, Oxford series in ecology and evolution. Oxford University Press, Oxford.

Fagan, K.A., Koops, M.A., Arts, M.T., Power, M., 2011. Assessing the utility of $\mathrm{C}: \mathrm{N}$ ratios for predicting lipid content in fishes. Can. J. Fish. Aquat. Sci. 68, 374-385.

Fry, B., 2006. Stable Isotope Ecology. Springer, New York, NY.

Fry, B., Scalan, R.S., Parker, P.L., 1977. Stable carbon isotope evidence for two sources of organic matter in coastal sediments: seagrasses and plankton. Geochim. Cosmochim. Acta 41, 1875-1877.

Graham, C.T., Harrison, S.S.C., Harrod, C., 2013. Development of non-lethal sampling of carbon and nitrogen stable isotope ratios in salmonids: effects of lipid and inorganic components of fins. Isotopes Environ. Health Stud. 49, 555-566.

Haines, E.B., 1976. Relation between the stable carbon isotope composition of fiddler crabs, plants, and soils in a salt marsh. Limnol. Oceanogr. 21, 880-883.

Hesslein, R.H., Hallard, K.A., Ramlal, P., 1993. Replacement of sulfur, carbon, and nitrogen in tissue of growing broad whitefish (Coregonus nasus) in response to a change in diet traced by $\delta^{34} \mathrm{~S}, \delta^{13} \mathrm{C}$, and $\delta^{15} \mathrm{~N}$. Can. J. Fish. Aquat. Sci. 50, 2071-2076.

Hobson, K.A., 1999. Tracing origins and migration of wildlife using stable isotopes: a review. Oecologia 120, 314-326.

Hoffman, J.C., Sutton, T.T., 2010. Lipid correction for carbon stable isotope analysis of deep-sea fishes. Deep Sea Res. Part Oceanogr. Res. Pap. 57, 956-964.

Iverson, S., Lang, S., Cooper, M., 2001. Comparison of the Bligh and Dyer and Folch 
methods for total lipid determination in a broad range of marine tissue. Lipids 36, 12831287.

Jardine, T.D., Gray, M.A., McWilliam, S.M., Cunjak, R.A., 2005. Stable isotope variability in tissues of temperate stream fishes. Trans. Am. Fish. Soc. 134, 1103-1110.

Kiljunen, M., Grey, J., Sinisalo, T., Harrod, C., Immonen, H., Jones, R.I., 2006. A revised model for lipid-normalizing $\delta^{13} \mathrm{C}$ values from aquatic organisms, with implications for isotope mixing models. J. Appl. Ecol. 43, 12131222.

Logan, J.M., Jardine, T.D., Miller, T.J., Bunn, S.E., Cunjak, R.A., Lutcavage, M.E., 2008. Lipid corrections in carbon and nitrogen stable isotope analyses: comparison of chemical extraction and modelling methods. J. Anim. Ecol. 77, 838-846.

Logan, J.M., Lutcavage, M.E., 2008. A comparison of carbon and nitrogen stable isotope ratios of fish tissues following lipid extractions with non-polar and traditional chloroform/methanol solvent systems. Rapid Commun. Mass Spectrom. 22, 1081-1086.

MacAvoy, S.E., Macko, S.A., Garman, G.C., 2001. Isotopic turnover in aquatic predators: quantifying the exploitation of migratory prey. Can. J. Fish. Aquat. Sci. 58, 923-932.

McCarthy, M.D., Benner, R., Lee, C., Fogel, M.L., 2007. Amino acid nitrogen isotopic fractionation patterns as indicators of heterotrophy in plankton, particulate, and dissolved organic matter. Geochim. Cosmochim. Acta 71, 4727-4744.

McClelland, J.W., Holl, C.M., Montoya, J.P., 2003. Relating low ${ }^{15} \mathrm{~N}$ values of zooplankton to $\mathrm{N}_{2}$-fixation in the tropical North Atlantic: insights provided by stable isotope ratios of amino acids. Deep Sea Res. Part Oceanogr. Res. Pap. 50, 849-861.

McConnaughey, T., McRoy, C.P., 1979. Foodweb structure and the fractionation of carbon isotopes in the Bering Sea. Mar. Biol. 53, 257262.

Miller, M.J., Capriles, J.M., Hastorf, C.A., 2010. The fish of Lake Titicaca: implications for archaeology and changing ecology through stable isotope analysis. J. Archaeol. Sci. 37, 317-327.
Minagawa, M., Wada, E., 1984. Stepwise enrichment of ${ }^{15} \mathrm{~N}$ along food chains: Further evidence and the relation between $\delta^{15} \mathrm{~N}$ and animal age. Geochim. Cosmochim. Acta 48, 1135-1140.

Minson, D.J., Ludlow, M.M., Troughton, J.H., 1975. Differences in natural carbon isotope ratios of milk and hair from cattle grazing tropical and temperate pastures. Nature 256, 602-602.

Mintenbeck, K., Brey, T., Jacob, U., Knust, R., Struck, U., 2008. How to account for the lipid effect on carbon stable-isotope ratio $\left(\delta^{13} \mathrm{C}\right)$ : sample treatment effects and model bias. J. Fish Biol. 72, 815-830.

Monson, K.D., Hayes, J.M., 1982. Carbon isotopic fractionation in the biosynthesis of bacterial fatty acids. Ozonolysis of unsaturated fatty acids as a means of determining the intramolecular distribution of carbon isotopes. Geochim. Cosmochim. Acta 46, 139-149.

Perga, M.E., Gerdeaux, D., 2005. "Are fish what they eat" all year round? Oecologia 144, 598606.

Post, D.M., Layman, C.A., Arrington, D.A., Takimoto, G., Quattrochi, J., Montaña, C.G., 2007. Getting to the fat of the matter: models, methods and assumptions for dealing with lipids in stable isotope analyses. Oecologia 152, 179-189.

$\mathrm{R}$ Core Team, 2012. R: A Language and Environment for Statistical Computing. Version 2.15.2. http://www.R-project.org/.

RStudio, 2013. RSudio: Integrated development environment for $R$. Version 0.97.318. http://www.rstudio.org/.

Schoeninger, M.J., DeNiro, M.J., 1984. Nitrogen and carbon isotopic composition of bone collagen from marine and terrestrial animals. Geochim. Cosmochim. Acta 48, 625-639.

Serrano, R., Blanes, M.A., Orero, L., 2007. Stable isotope determination in wild and farmed gilthead sea bream (Sparus aurata) tissues from the western Mediterranean. Chemosphere 69, 1075-1080.

Van der Veer, H.W., Bauer, J., Aarts, G., Dekker, R., Diderich, W., Freitas, V., Witte, J.IJ., 2011. Long-term trends in juvenile flatfish indicate a dramatic reduction in nursery function of the Balgzand intertidal, Dutch Wadden Sea. Mar. Ecol. Prog. Ser. 434, 143-154. 
Vinagre, C., Máguas, C., Cabral, H.N., Costa, M.J., 2011. Nekton migration and feeding location in a coastal area - A stable isotope approach. Estuar. Coast. Shelf Sci. 91, 544550.

Vinagre, C., Salgado, J., Costa, M.J., Cabral, H.N., 2008. Nursery fidelity, food web interactions and primary sources of nutrition of the juveniles of Solea solea and $S$. senegalensis in the Tagus estuary (Portugal): A stable isotope approach. Estuar. Coast. Shelf Sci. 76, 255264.

Vollaire, Y., Banas, D., Thomas, M., Roche, H., 2007. Stable isotope variability in tissues of the Eurasian perch Perca fluviatilis. Comp. Biochem. Physiol., Part A: Mol. Integr. Physiol. 148, 504-509.
Willis, T.J., Sweeting, C.J., Bury, S.J., Handley, S.J., Brown, J.C.S., Freeman, D.J., Cairney, D.G., Page, M.J., 2013. Matching and mismatching stable isotope $\left(\delta^{13} \mathrm{C}\right.$ and $\left.\delta^{15} \mathrm{~N}\right)$ ratios in fin and muscle tissue among fish species: a critical review. Mar. Biol. 160, 1633-1644.

Wolf, N., Carleton, S.A., Martínez del Rio, C., 2009. Ten years of experimental animal isotopic ecology. Funct. Ecol. 23, 17-26.

Xia, B., Gao, Q., Li, H., Dong, S., Wang, F., 2013. Turnover and fractionation of nitrogen stable isotope in tissues of grass carp Ctenopharyngodon idellus with emphasis on the role of growth and metabolism. Aquac. Environ. Interact. 3, 177-186. 